\title{
Friends' Quarrel: Speech Event Equivalence in Subtitle
}

\author{
Jotika Purnama Yuda ${ }^{1}$, Mangatur Nababan ${ }^{2}$, Djatmika ${ }^{3}$ \\ \{jo.purnama.yuda@student.uns.ac.id ${ }^{1}$, amantaradja@yahoo.com ${ }^{2}$, djatmika@uns.ac.id ${ }^{3}$ \} \\ ${ }^{1,2,3}$ Linguistics of Translations Graduate program of Universitas Sebelas Maret, indonesia
}

\begin{abstract}
For film subtitle to be referred to as a portrayal of certain culture, maintaining the message integrity delivered in the source text social context is essential. This research seeks to analyze the translation equivalence at speech event level of friends' quarrel by looking at its constructing elements, namely its genre; speech acts used within friends' quarrel speech events. The data were collected purposively and analyzed using document analysis and focused group discussion. The findings conclude that there are four types of speech acts found in friends' quarrel with the following comparison between source language and target language: expressive (33:30), assertive (21:21), directive (15:14), and commisive $(3: 1)$. The domination of expressive speech act emphasizes the emotional characteristic of quarrel, and the least occurence of commissive speech act show that a quarrel may or may not have closure depending on the willingness of one party to admit mistake or to commit to do better. The genre, in terms of speech acts used, was maintained in the target language subtitle, but there were some speech acts ommited in the target language subtitle, thus affecting the genre in term of speech acts occuring frequency.
\end{abstract}

Keywords: Speech Event, Quarreling, Translation Equivalence, Speech Act

\section{INTRODUCTION}

The world of film industry has developed very rapidly, both in terms of technology and story ideas. The variety of film story ideas with different cultural backgrounds can be a medium of cultural learning.[1] One of the types of culture that can be learned from film is the way that a society communicates using the original language in accordance with the social norms and language applicable in the community.

Subtitling is a written translation that is usually placed at the bottom of the screen with the aim of conveying messages from dialogues displayed in audio visual media [2]. As a type of translation, subtitling has limitations that often make it difficult for translators (subtitlers) to deliver messages from the source language as a whole. Some examples of these limitations are provisions regarding the maximum number of lines that cannot be more than two lines with an average of 37 letters on each row and a duration of display that is no more than 6 seconds [3]. With these limitations, there are many cases in which subtitlers have to sacrifice the integrity 
of a message both in terms of meaning and linguistic structure. This often causes a shift in subtitle translation results which will of course affect the quality of the translation.

Speech events are linguistic interactions that occur between two or more parties as addressees and speech partners to discuss a particular subject matter in the context of a particular time, place, and situation [4]. A sentence in use is never independent, but it is a part of a situation or text. The context and flow of information presentation has an important role in creating the full meaning of a message.

Each community has certain linguistic rules or cultures that are used in each context of a speech event. The language rules or culture can be categorized as genres. This is in line with what is claimed by an expert that speech events can simply be matched with the genre [5]. In the context of translating subtitles, with two different cultures from the source language and the target language, a subtitler has the choice to maintain the genre from the source language or adapt it to the target language. The choices made by the subtitler will certainly affect the accuracy of meaning and acceptability in the target language.

The quality of translation can be viewed from three components, namely the accuracy, acceptability and readability [6]. The limited space for translators to translate subtitles will certainly impact the quality of the translation both in terms of accuracy and acceptability. The quality of translations in terms of accuracy and acceptability can be assessed by various linguistic approaches such as sociolinguistics, functional systemic linguistics, and pragmatics.

In terms of pragmatics, research regarding speech acts used in specific situation and genre have been conducted extensively such as the use of explicit illocutionary act used in legislative discourse, speech acts used in advertising, and in apology [7] [8] [9]. Those researches, even though taking on the very similar subject, did not specifically refer to the research subject as speech event. Other more specific research on speech events that have been carried out by several previous researchers are the analysis of speech events of the "Mchongoano" language game in Kenya, and speech events found in the television series "Friends" [10], [11]. However, the authors have not found any previous research that specifically examines the speech event of quarreling and its relation to the fields of translation equivalence.

Several other researches on translation using pragmatics and socio-linguistic approaches have also been conducted such as regarding the assertive speech acts employed in two different time frame versions of translation and the translation analysis of introduction and wishes found in TV series subtitle [12] [13]. However, most of these studies only examine equivalence at the sentence or speech act level and have not examined the broader structure such as speech events and speech situations.

If film subtitles is to be referred to as a portrayal of certain culture, it is essential to maintain the integrity of the message delivered in the social context of the source text society. The state of the art of this research is to analyze the translation equivalence at speech event level of quarreling by looking at its constructing elements, namely its genre; speech acts used within the speech event.

\section{METHOD}

This study was an embedded case study using descriptive qualitative method because the data collected were in the form of sentences that accommodate speech acts found in quarreling speech event in Ted 2 subtitles. This research also refered to ethnographic methods because the researchers were also involved in analyzing the data by interacting further and given more roles to, finally, drew conclusions themselves [22]. The data were collected using purposive 
sampling which were then analyzed using analysis and focused groups discussion to obtain more than an understanding to answer the research question.

\section{RESULT AND DISCUSSION}

\subsection{Speech Event}

One expert who proposed a fairly complete formula regarding the components of speech events was Hymes. Hymes suggests that there are eight components in speech events that can be abbreviated with the acronym SPEAKING, which means Settings and Scenes (background place, time, and situation), Participants (Actors, speakers and partners). ), Ends (purpose), Act Sequence (form, sequence and content of speech), Key (how to convey speech or tone of speech), Instrumentalities (variety of languages used), Norm of Interaction (norms or rules of language), Genres (types or forms of interaction, including speech acts used and flow of interactions) [14].

Hymes also provided an analogy that if a party is a speech situation, the conversation in the party is a speech event, and the utterances in the conversation are speech acts [7]. There are various kinds of speech events which usually have unwritten rules that apply to each community group such as speech events in buying and selling transactions, marriage proposal, negotiating, telephone, and so on.

\subsection{Speech Act}

Austin distinguishes three types of speech acts, namely: locutionary act (taking action to say something), illocutionary act (doing something in saying something); in saying $X$, the speaker perform $\mathrm{P}$ ( $\mathrm{P}$ is the power of action or attitude carried out by saying $\mathrm{X}$ ), and perlocutionary act (the effect of an action driven by a speech) by saying $X$, the speaker assures the speech partner to do $\mathrm{P}$ ( $\mathrm{P}$ is an action or attitude that must be done). This concept was used by previous research to approach the genre of nomination speech [15].

Furthermore, due to the nature of illocutionary speech acts that can have different meanings from their literal meanings, Searle classified illocutionary speech acts into 5 groups: assertive speech acts, directive speech acts, commissive speech acts, expressive speech acts, and declarative speech acts [16]. The authors employed Searle's argument in this study to classify the types of speech acts that occur in quarreling speech events.

\subsection{Quarreling}

One of interesting speech events to discuss is quarreling. Some dictionary definitions of quarreling are as follows; A heated argument or disagreement, typically over a trivial issue and between people who are usually on good terms [17]; an angry disagreement between two people or more or groups [18]; and an angry argument or disagreement [19]. Meanwhile, argument itself is "Speech events related to disagreement" characterized by projection, production, suppression, or resolution of disagreement [20]. The argument does not only serve to convey cases of explicit disagreement but also regulate mutually disagreeable speech acts (ibid). By combining the definition of quarreling from several dictionaries and the description of the arguments in the scientific journal above, an interesting phenomenon was found, that quarreling speech event in general is included in the genre of argumentation, which is usually carried out more systematically, subsequently giving statements, arguments, and responses. However, because of the emotional nature of quarreling, it can have a different genre from the argumentation in general.

One of the films that accommodates many scenes of quarreling spech events is the film Ted 2. This film is a sequel to the film Ted which tells the story of a young man who befriends 
a Teddy Bear who can talk. Although it is a fictional film, the story in Ted's film shows a strong friendship relationship that is common in young people in American society. Ted film became a box office and made a profit of $\$ 549,368,315$ in 2012 [21]. Because of its success, the sequel to the film Ted was released as Ted 2 in 2015. Although Ted 2's film was not as successful as its first film, judging from the achievement of a profit of $\$ 215,863,606$, this film is interesting to study because the closer friendship between its characters in the film leads to stronger and more complex problems in it. Quarrel in this study is limited to friends' quarrel because in this film there are two scenes featuring friends' quarrel, so it is expected to find more comprehensive results than other quarrel scenes such as lovers' quarrel, neighbors' quarrel and enemies' quarrel that mostly only consists of one scene.

Ted 2 film tells the story of Ted, a Teddy Bear character who can talk to his best friend John. The conflict in Ted 2's film began when Ted got married to a woman named Tamy Lynn. Ted's marriage with Tamy Lynn faced many problems due to the economy and Ted's physiolog. Furthermore, because Ted's character was not human, his marriage to Tamy Lynn was legally problematic. The story then revolved around the problems that caused a fight between Ted and his wife and with John, a friend who was triying to help him. The quarrel that occurred between Ted, Tamy, Samantha and John was good sources of data to be studied regarding the quarreling speech events because it fulfills the definition presented above, namely emotional argumentation or disagreement between two or more people who are usually well connected. There are two scenes of friends' quarrel in the film Ted 2. And here are the speech acts found in these quarrel friends:

Table 1. Speech Acts in Friends' Quarrel 1

\begin{tabular}{|c|c|c|c|}
\hline \multicolumn{2}{|c|}{ Source Language } & \multicolumn{2}{c|}{ Target Language } \\
\hline Speech Acts & Number & Speech Act & Number \\
\hline Assertive & 17 & Assertive & 17 \\
\hline Expressive & 9 & Expressive & 7 \\
\hline Directive & 9 & Directive & 8 \\
\hline Commissive & 3 & Commissive & 1 \\
\hline
\end{tabular}

From the table above, it can be seen that there are 4 types of speech acts that occur in the events of the friends' quarrel 1, namely; asertive, expressive, directive, and commissive. Asertive speech acts that occur are in the form of expressing, asking, confessing and answering, while some expressive speech acts that appear are expressions of expressing anger, surprise and regret. This quarrel occured when Ted's character discovered that his friend Johnny is addicted to porn. This caused Ted to be surprised, angry, and then they argued with each other about this. The directive speech acts that come up are asking and telling, and the commissive speech acts that occur is promising. The commissive speech acts occured when Johnny's character later admitted his mistake, which was followed by Ted's request that Johnny needed to fix himself in the future. Johnny then promised not to repeat his actions. The fight ended with one party acknowledging his mistake and promising to correct the mistakes he had made in the future.

From the data above, it can also be seen that there is a shift in the number of speech acts on the target language that decreased. This is because some speeches were not translated by subtitlers so that there are several speech acts missing from the target language. The loss of two expressive speech acts, one directive speech act and two commisive speech acts, although not changing the genre in terms of the types of speech acts that arise, reduces the accuracy in 
terms of the frequency of appearance of the speech act in the genre of this quarreling speech event.

Table 2. Speech Acts in Friends' Quarrel 2

\begin{tabular}{|l|c|l|c|}
\hline \multicolumn{2}{|c|}{ Source Language } & \multicolumn{2}{c|}{ Target Language } \\
\hline \multicolumn{1}{|c|}{ Speech Acts } & Number & Speech Act & Number \\
\hline Assertive & 4 & Assertive & 4 \\
\hline Expressive & 24 & Expressive & 23 \\
\hline Directive & 6 & Directive & 6 \\
\hline
\end{tabular}

From the table above, it can be seen that there are 3 types of speech acts that appear in the events of the friends' quarrel 2, namely; assertive, expressive, and directive. The directive speech acts that occur are asking and telling. The assertive speech acts that occur are in the form of expressing, asking, and answering, while some expressive speech acts that occur are expressions of disappointment, anger, and blame. The speech event occured when Ted was disappointed and angry because his case was defeated in court, and he blamed the character of Johnny and Samantha who were getting closer at the moment when he had hardship. However, Johnny, who had struggled to defend Ted from the start, could not accept Ted's action that was blaming them. Friends' Quarrel 2 did not end well because no one wanted to succumb to the requests or accusations from each character. The fight ended with the character Ted leaving Johnny and Samantha.

From the data above, it is found that one speech act is lost in the target language, namely the expressive speech act. Just like the Friends' Quarrel 1, the loss of speech acts caused by the translation process performed by the subtitler in the target language does not cause any changes in the types of speech acts that occur in the quarreling speech event. The types of speech acts that occur in the source language and target language remains the same, the shift that occurs only affects the number of speeches that occur that results in decreased accuracy in the target language subtitle [23].

\section{CONCLUSION}

Quarreling speech event ini these two cases of friends' quarrels may comprise of assertive, directive, expressive, and commisive speech acts. The occurence of expressive speech act as the most frequently used speech act in quarreling emphasizes the emotional feature of quarrel, and the occurence of assertive speech act as the second most frequently occuring speech act shows the argumentative nature of a quarrel. Meanwhile, the commissive speech act, as the least frequently occuring speech act, shows a hint of the tentative nature of closure in quarreling, which is dependant on the willing of one side of the participant to agree or admit mistake and to promise to make improvement.

The identity of a speech event in a cultural context is formed by speech acts that are socially used in it. In the context of cultural introduction and learning, using film subtitles, a subtitler should be able to give priority to convey the intended meaning of an utterance and not be limited to the literal meaning, so that the integrity of the speech event in a cultural context within the source language community can be maintained. The failure of a subtitler in understanding the intended meaning of a speech or speech act contained in a speech event can reduce the integrity of the message in the cultural context of the community that is portrayed in a film pragmatically and sociolinguistically. 


\section{REFERENCES}

[1] M. Chen, Effects of integrating children's literature and DVD films into a college EFL class. 2012.

[2] G. Cintas, J. D., \& Anderman, Audiovisual Translation: Language Transfer on Screen. London: Palgrave Macmillan., 2009.

[3] B. Khalid Khalad, "an Introduction To Subtitling: Challenges and Strategies," Int. J. Comp. Lit. Transl. Stud., vol. 3, no. 1, 2016.

[4] A. Purba, "Tindak Tutur dan Peristiwa Tutur," J. Pena, vol. 1, 2011.

[5] P. Grundy, Doing Pragmatics. New York: Oxford University Press, 2000.

[6] \& S. Nababan, M., Nuraeni, A., "Pengembangan Model Penilaian Kualitas Terjemahan," Kaji. Linguist. Dan Sastra, vol. 24, no. 1, pp. 39-57, 2012.

[7] C. Unoalegie, B. Agbara, and K. Omole, "Explicit Illocutionary Acts in Legislative Discourse," vol. 2, no. 3, pp. 28-36, 2015.

[8] S. Simon, "Speech Acts in Written Advertisements: Identification, Classification and Analysis," Procedia-Social Behav. Sci. Elsevier, vol. 192, pp. 234-239, 2015.

[9] A. A. A. Banikalef and M. Maros, "Social Beliefs for the Realization of the Speech Acts of Apology among Jordanian EFL Graduate Students," English Linguist. Res., vol. 2, no. $1,2013$.

[10] C. P. Kihara, "Mchonoano and Ethnography of Communication," Univ. Nairobi J. Lang. Linguist., vol. 4, pp. 1-19, 2015.

[11] F. Zand-Vakili, Elham; Kashani, Alireza Fard; Tubandeh, "The Analysis of Speech Events and Hymes' Speaking Factors in the Comedy Television Series 'FRIENDS.,"' New Media Commun. J., vol. 2, 2012.

[12] I. Ilham, M. R. Nababan, D. Kristina, and T. Wiratno, "The Evolution of Booster on the Assertive Speech Act Used in Two Decades Version of Translation," vol. 166, no. Prasasti, pp. 546-551, 2018.

[13] V. Bonsignori, "Translating introductions and wishes in audiovisual dialogue. Evidence from a corpus Veronica Bonsignori 1 Silvia Bruti."

[14] E. Kalou, Z \& Sadler-Smith, "Using Ethnography of Communication in Organizational Research.," SAGE Journal, vol. 18, no. 4, 2015.

[15] S. A. Akinwotu, "A Speech Act Analysis of Nomination Speeches of Chief Obafemi Awolowo and Chief M.K.O Abiola.," English inguistic Res., vol. 2, no. 1, 2013.

[16] J. R. Searle, Expression and Meaning. Cambridge: Cambridge University Press, 2005.

[17] Oxford University, "Quarrel definition," 2018. [Online]. Available: https://en.oxforddictionaries.com/definition/quarrel. [Accessed: 14-Sep-2018].

[18] Cambridge University, "Quarrel Definition." [Online]. Available: https://dictionary.cambridge.org/dictionary/english/quarrel. [Accessed: 14-Sep-2018].

[19] Merriam-webster, "quarrel definition," 2018. [Online]. Available: https://www.merriamwebster.com/dictionary/quarrel.

[20] H. Koczogh, "Scrutinizing the Concept of (Verbal) Disagreement," Argumentum, vol. 9, no. Debreceni Egyetemi Kiadó, pp. 211-222, 2013.

[21] IMDB, “Ted 2 Movies." [Online]. Available: https:/www.imdb.com/title/tt1637725/. [Accessed: 14-Sep-2018].

[22] R. Santosa, Metode Penelitian Kebahasaan. Surakarta: UNS Press., 2017.

[23] K. Saddhono, "Language of Coastal Communities in the Northern Coast of Central Java: 
Sociolinguistic Studies in Cultural Integration Maritime-Agrarian Perspective." Adv. Sci. Let. vol. 23 no. 10 pp 10054-10056, 2017 